\title{
Late Permian (Zechstein) carbonate-facies maps, the Netherlands
}

\author{
M.C. Geluk ${ }^{1}$ \\ Netherlands Institute of Applied Geoscience TNO - National Geological Survey, P.O. Box 80015, \\ 3508 TA UTRECHT, the Netherlands; e-mail: m.geluk@nitg.tno.nl
}

Manuscript received: 18 December 1998; accepted in revised form: 12 November 1999

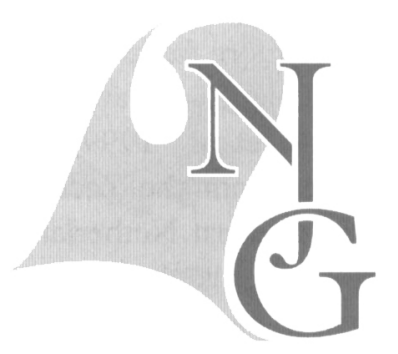

\begin{abstract}
The Late Permian Zechstein carbonates in the Southern Permian Basin were deposited under marine conditions. The carbonates form part of a largely progradational infill, with a gradual northward facies shift. The paleogeography of the Zechstein carbonate deposits has been reviewed recently on the base of well data, cores and publications. This has resulted in three updated maps of the carbonate units. These maps reflect the increase in knowledge of the palaeogeography of the Zechstein as a result of several decades of subsurface exploration. It is found that deposition of the carbonates was controlled by various factors, i.e., rifting during deposition of the basal Zechstein, sea-level fluctuations and basin subsidence. This resulted in an overall E-W orientated facies distribution in the Zechstein carbonates, and in the gradual northward shift of the various facies belts in time.
\end{abstract}

Reefs in the Z1 Carbonate Member and off-platform highs and turbidites in the Z2 Carbonate Member have been identified as potential future exploration targets.

Keywords: evaporite cycles, NW Europe, palaeogeography, Southern Permian Basin

\section{Introduction}

Zechstein deposits have been first encountered in the subsurface of the Netherlands almost a century ago. In 1905, the Helenaveen-5A well in the southeastern part of the Netherlands encountered a series of carbonates and claystones below the Early Triassic sandstones; the carbonates were attributed to the Late Permian Zechstein (Van Waterschoot van der Gracht, 1918). The Zechstein was known already long before from outcrops, wells and mine-shafts in the adjacent part of NW Germany, so it was no surprise when the presence of the deposits was proven in the Netherlands during the first Governmental drilling campaign. The first natural-gas discovery in the Zechstein carbonates in the Netherlands dates back to 1948 , following earlier discoveries in the adjacent part of Germany (Bad Bentheim in 1938). Since this period, and particularly since the discovery of natural gas in the underlying Upper Rotliegend deposits, more than 3000 boreholes penetrated the
Zechstein in both the onshore and offshore areas.

The Zechstein Group in the Netherlands comprises up to five evaporite cycles, each with status of a formation. In the group, a twofold subdivision can be made based upon the depositional character into marine evaporite deposits in the lower part of the group (i.e., the Z1, Z2 and Z3 Formations) and playa-type deposits in the upper part (the Z4 and Z5 Formations) (Geluk et al., 1997). The occurrence of carbonates is restricted to the basal part of the marine evaporite cycles. Three carbonate intervals have been identified throughout the Southern Permian Basin. They are known in the Netherlands as the Z1-Z3 Carbonate Members. The German names of Zechsteinkalk, Hauptdolomit and Plattendolomit (RichterBernburg, 1955) are frequently used throughout the Southern Permian Basin.

In the Netherlands and adjacent areas, the Zechstein evaporite deposits do not only effectively seal the Upper Rotliegend gas reserves, but form themselves interesting targets for gas exploration, with commer- 
cial quantities of natural gas mainly in the $\mathrm{Z} 2$ and $\mathrm{Z3}$ Carbonates $\left(150 \cdot 10^{9} \mathrm{~m}^{3}\right.$ GIIP; Geluk et al., 1997). Natural-gas fields in the eastern Netherlands contain over half of this amount of gas $\left(80 \cdot 10^{9} \mathrm{~m}^{3}\right.$ GIIP; Van der Baan, 1990). One of the gas fields has recently been converted into an underground gas-storage facility. The first small amount of crude oil in the Netherlands was actually produced both from the Carboniferous and Zechstein in 1924 (well Corle-1: 240 liters of light crude). Several small oil accumulations have been found in the Zechstein reservoirs since (Fig. 1). They occur more frequently in central and eastern Germany and Poland (see, among others, Gerling et al,. 1996a,b; Górski et al., 1999). Besides hydrocarbons, thermal brines from the Zechstein are used for a spa in the southeastern Netherlands (Arcen-1). Studies revealed that there is also scope for similar applications in the eastern Netherlands (Zuurdeeg et al., 1984).

The aim of the present contribution is to present three updated facies maps of the Zechstein carbonates, which form an addition to other palaeogeographic maps of the Zechstein Group in the Netherlands (Geluk et al., 1997). These maps have been compiled during the work for the NW European Gas
Atlas (Lokhorst, 1998), but only one of them (the Z2 Carbonate facies map) has been included in this atlas (Fig. 2). The present contribution comprises an overview of the working method and brief explanatory notes to the lithological characterisation of these carbonate units. Subsequently, the depositional history of the carbonate units, the origin of the relief in the Zechstein basin, the reliability of the maps, and additional hydrocarbon prospectivity will be discussed.

\section{Previous work and database used}

The Zechstein in the Netherlands was the subject of several papers. Visser (1955), Brueren (1959), Van Adrichem Boogaert \& Burgers (1983), Clark (1986), Van der Poel (1987, 1989), Van der Baan (1990), Van der Sande et al. (1996), Geluk et al. $(1996,1997)$ and Geluk (1999) presented details on the sedimentology, paleogeography, reservoir development and tectonics. The stratigraphic framework of the Zechstein has been published by Van Adrichem Boogaert \& Kouwe (19931997).

The database for the present contribution consists of core and $\log$ data from released offshore and on-

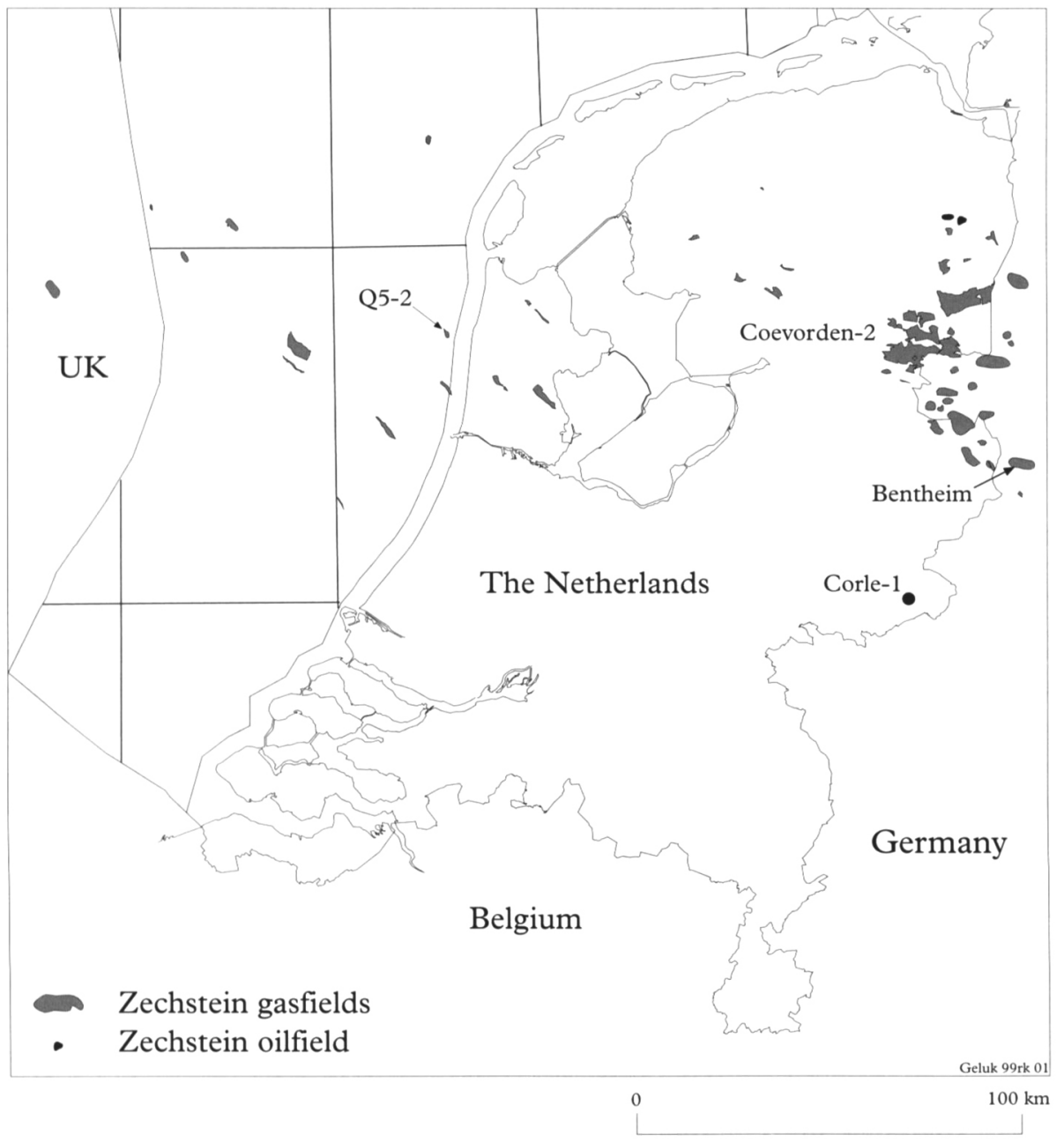

Fig. 1. Overview of the Zechstein gasfields in the Netherlands and adjacent areas. Further shown are the location of the first oil discovery well Corle-1 (1923), the first gas discovery in Bad Bentheim in NW Germany (1938) and the first gas discovery in the Netherlands, Coevorden-2 (1948). Q5-2 has been the only gas discovery in the $\mathrm{Z} 1$ Carbonate Member in the Netherlands (see text). 


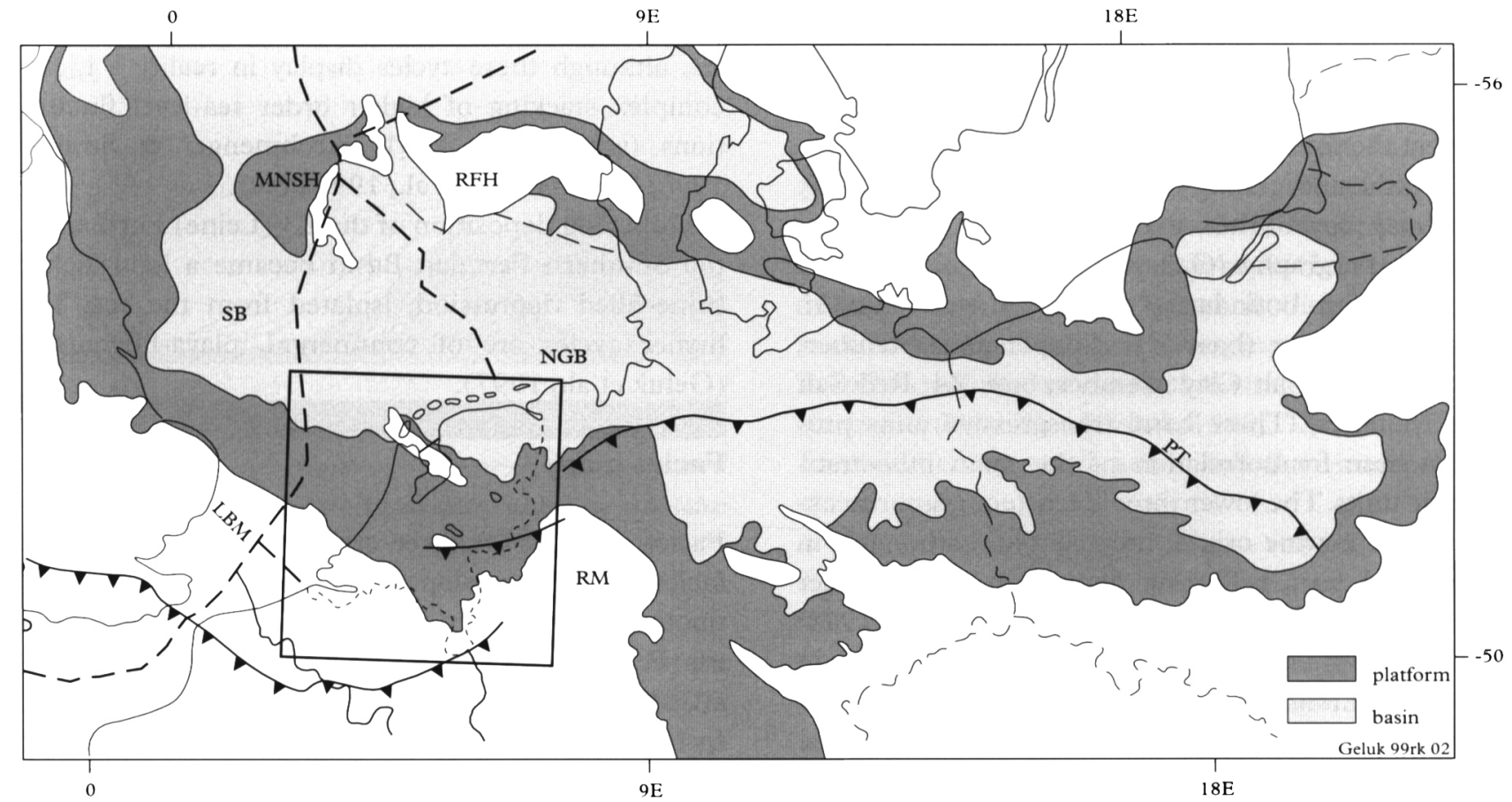

Fig. 2. Sketch map of the Late Permian basin (after Lokhorst, 1998; Taylor, 1998). The basin bordered by the Mid North Sea High and Ringkøbing-Fyn High in the North and the London-Brabant Massif and Rhenish Massif in the south is referred to as the southern Permian Basin. The solid black line represents the location of the Variscan Front.

MNSH: Mid North Sea High; RFH: Ringkøbing-Fyn High; SB: Silverpit Basin, LBM: London-Brabant Massif; RM: Rhenish Massif; NGB; North German Basin; PT: Polish Trough.

shore wells and the literature (Fig. 3). Rough sketch versions of Zechstein carbonate facies maps were already published by Dorsman (1954) and Visser (1955). Both maps were based upon a limited well database and have therefore limited value. The regional mapping programme of the onshore area of the Netherlands provides many details on the Zechstein (RGD, 1991a,b, 1993a,b, 1995; NITG, 1998). Studies from adjacent parts of Germany, the UK and Belgium are important for correlation of the maps across the international borders; reference is made to Wolburg (1957), Füchtbauer (1980), Paul (1980), Hilden (1988), Demyttenaere (1989), Wolf (1985), M.A. Ziegler (1989), Cameron et al. (1992), Strohmenger et al. (1996a) and Taylor (1998).

\section{Palaeogeographical setting and Zechstein strati- graphy}

The study area is situated in the western part of the Southern Permian Basin, a large intracratonic basin stretching from the UK in the west to Poland and Lithuania in the east. This basin was bordered to the

Fig. 3: Overview of the well database used for the present contribution. For the hatched area in the eastern Netherlands, a 3-D isopach map for the Z2 Carbonate was published by Van der Sande et al. (1996).

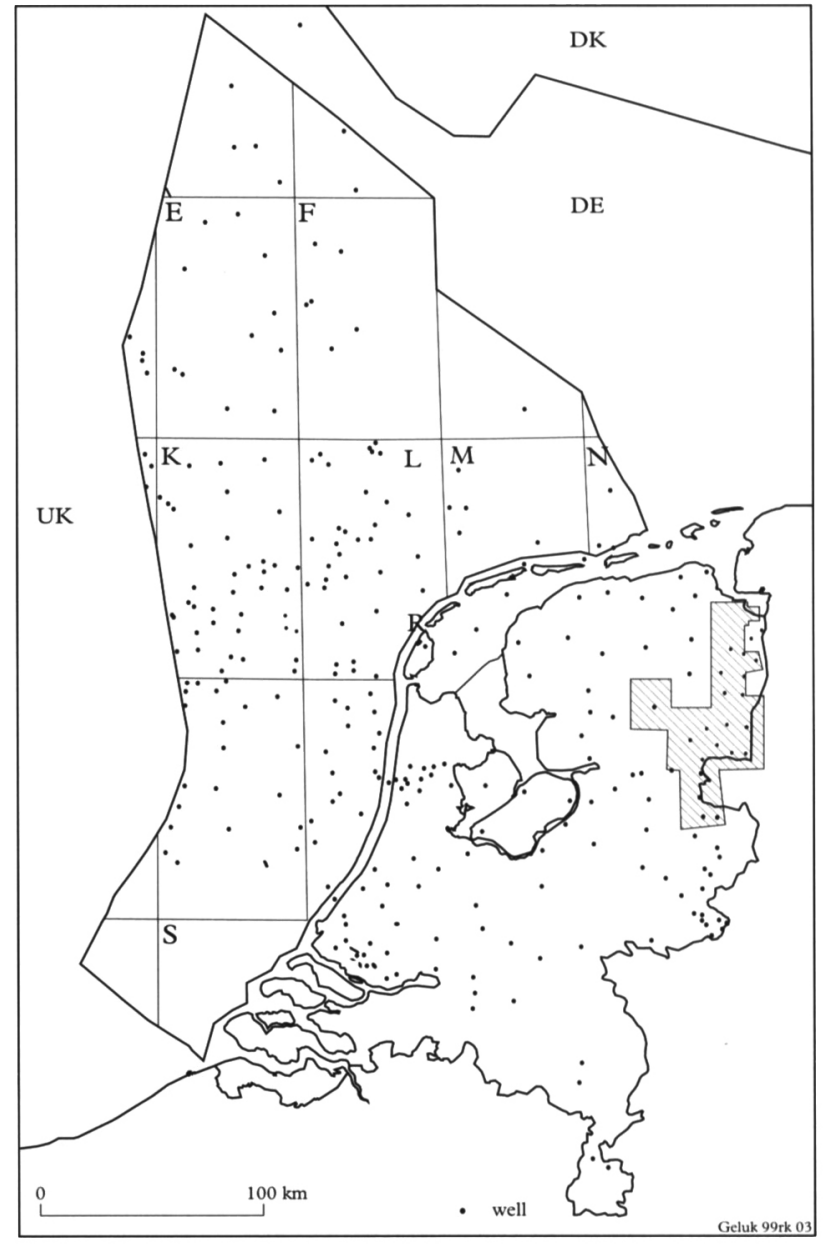


south by the London-Brabant Massif and the Rhenish Massif, and to the north by the Mid North Sea and Ringkøbing-Fyn High. The Netherlands were situated at the southern margin of this basin (Fig. 2).

The lithostratigraphy of the Zechstein Group (Fig. 4) closely approaches the concepts of genetic sequence stratigraphy (Galloway, 1989) since most of the formation boundaries are picked at maximum flooding surfaces (base Z1: Coppershale Member; base Z3: Grey Salt Clay Member; base Z4: Red Salt Clay Member). These basal transgressive units provide a base for correlation of the main lithostratigraphic units. The lower three Zechstein evaporite cycles are of marine origin; they contain carbonates in their basal part, reflecting deposition in sea water with normal salinities (a.o.: Sannemann et al., 1978; Taylor, 1998). The overlying anhydrites and salts in these cycles reflect the progressive evaporation of the sea water (Richter Bernburg, 1955). For the purpose of the present contribution, the Zechstein formations will be regarded as single transgressive/regressive cycles, although these cycles display in reality a highly complex stacking of higher order sea-level fluctuations (see Tucker, 1991; Strohmenger \& Strauss, 1996; Strohmenger et al., 1996a,b,c).

Following deposition of the Z3 (Leine) Formation, the Southern Permian Basin became a land-locked brine-filled depression, isolated from the sea. The higher cycles are of continental, playa-like origin (Geluk et al., 1997).

\section{Facies maps}

Facies maps of the three carbonate units show three facies types: basin, slope and platform facies. This distinction is commonly applied elsewhere in the Southern Permian Basin (by, among others, Cameron et al., 1992; Wagner, 1994; Strohmenger et al., 1996a). In N-S sections, at right angles to the basin axis, the carbonate units have a well-defined sigmoidal shape

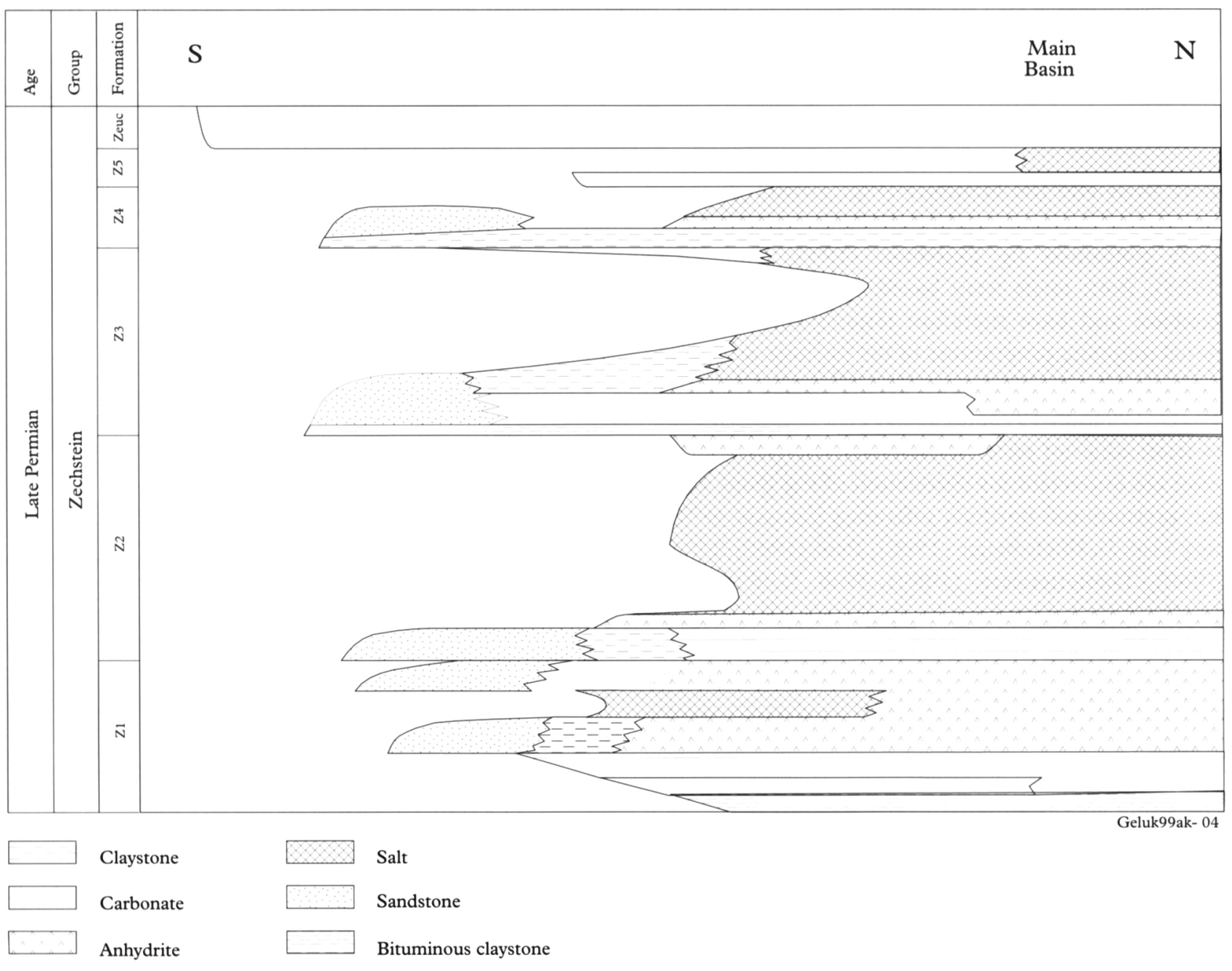

Fig. 4. Schematic stratigraphic diagram of the Zechstein Group (Late Permian) from basin fringe to basin centre. The carbonates discussed in the present contribution occur in the $Z 1, Z 2$ and $Z 3$ Formations.

Z1: Z1 (Werra) Formation; Z2: Z2 (Stassfurt) Formation; Z3: Z3 (Leine) Formation; Z4: Z4 (Aller) Formation; Z5: Z5 (Ohre) Formation; ZEUC: Zechstein Upper Claystone Formation. 


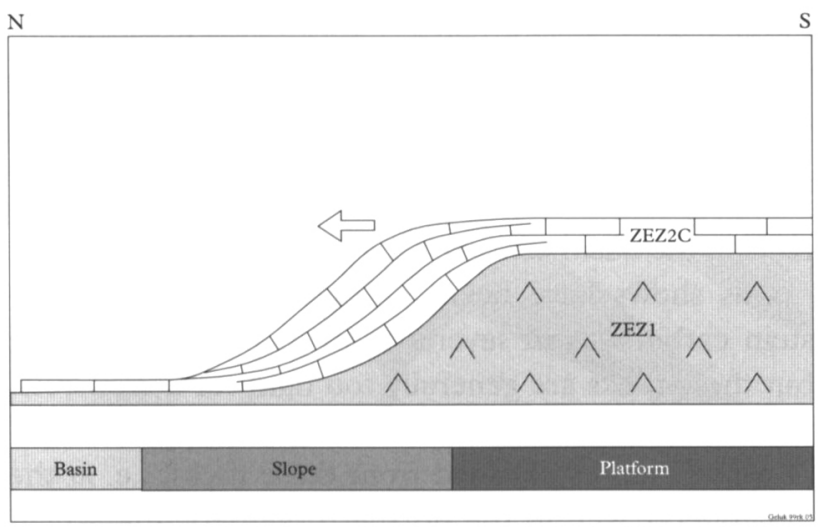

Fig. 5. Schematic model of a progradational carbonate unit (after Van der Sande et al., 1996). Note the well defined sigmoidal thickness shape of the unit.

(Fig. 5). This is commonly recognised throughout the Southern Permian Basin (Sannemann et al., 1978; Cameron et al., 1992; Strohmenger et al., 1996a; Taylor, 1998) and reflects the progradational or aggradational infill of the basin (Clark, 1986; Van der Sande et al., 1996). This sigmoidal shape is caused by a thinning of the carbonate unit on both the landward and the basinal side, with a maximum thickness development on the carbonate slope or the transition to the platform. In the $\mathrm{Z} 1$ Carbonate Member, local disturbances of this generalised isopach pattern occur, suggested to be the effect of synsedimentary tectonics (M.A. Ziegler, 1989; Geluk, 1999).

\section{Z1 Carbonate Member (Zechsteinkalk)}

This lowermost carbonate member was deposited during the initial Zechstein transgression. In most of the area it overlies the Coppershale Member, except in the southern onshore area of the Netherlands, NE Belgium and the Osnabrück area in Germany (Paul, 1980), where it onlaps Upper Rotliegend or Carboniferous deposits. The palaeogeography of this unit is influenced by extensional tectonics prior to and during its deposition (Geluk, 1999). The map (Fig. 6) has been constructed using well data and publications.

\section{Basin facies}

The basin facies covers most of the study area, and typically has a thickness of $5-10 \mathrm{~m}$. The $\mathrm{Z} 1$ Carbonate consists of brown limestones and organic rich dolomites. In the top part, however, a completely different lithofacies association occurs, with oncolites and anhydrite nodules in an area from the UK to Poland (Brueren, 1959; Wagner, 1994; Taylor, 1998).

The basin facies is suggested to have been deposited in a water depth of several tens of meters, except for the top part, where the oncolites and anhydrite nodules reflect a serious drop of the sea level (Taylor, 1998) and are more indicative for platform conditions.

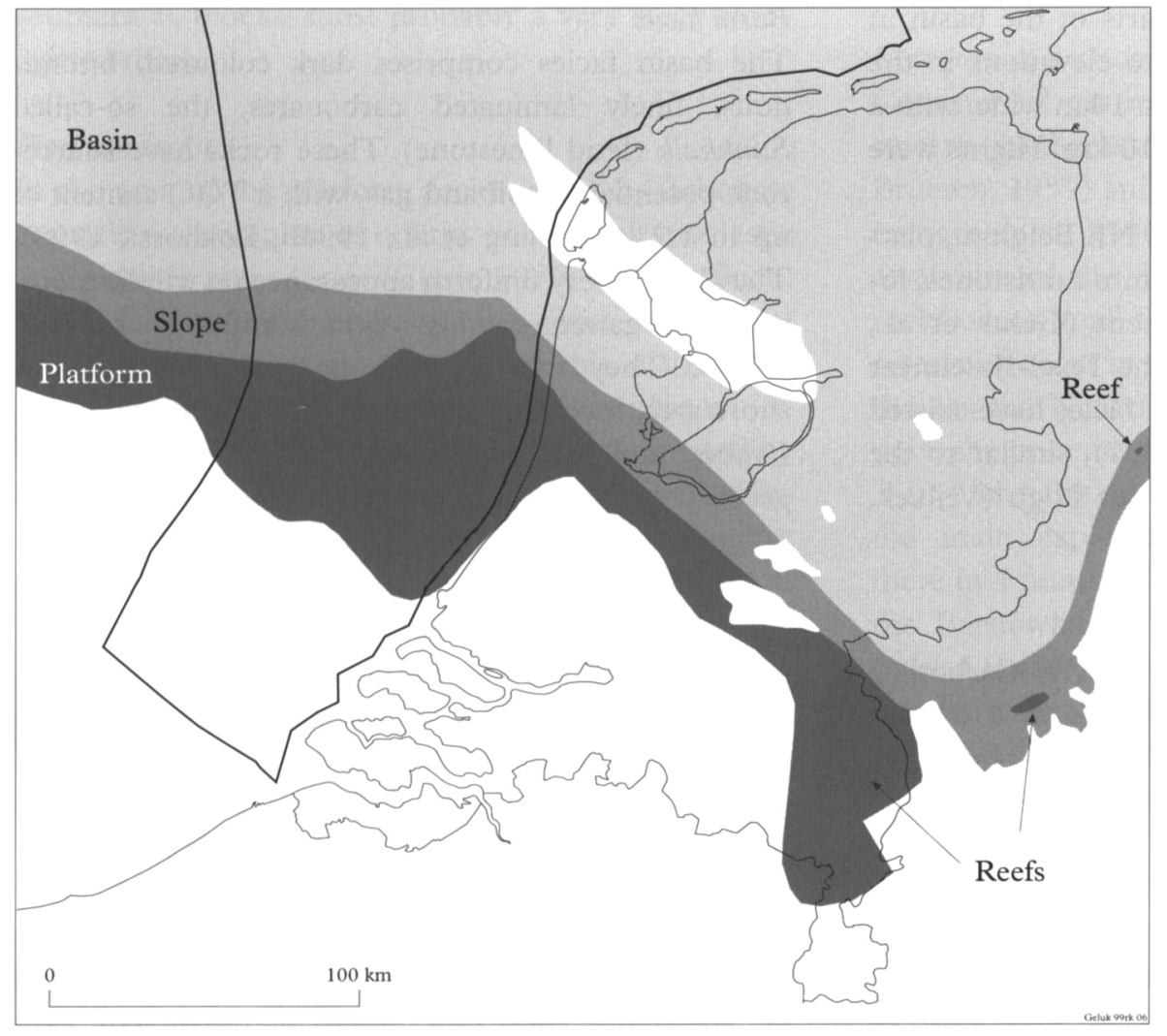

Fig. 6. Facies map of the $\mathrm{Z} 1$ Carbonate Member. This map is based on well data and literature. The part covering the UK has been adopted from Cameron et al. (1992); the part covering Germany has been adopted from Füchtbauer (1980). The light areas in the onshore part of the Netherlands are highs where the Zechstein has been eroded in Late Jurassic to Early Cretaceous times. 
Slope facies

The slope facies comprises a succession dominated by foreshore mudstones and claystones, grading upwards into marlstones and (oolitic) platform limestones and dolomites near the top of the unit. In the onshore area of the Netherlands, this facies reaches a thickness of up to several tens of meters, but in the offshore area the thickness reaches up to $150 \mathrm{~m}$. The upward increase of the carbonate content is interpreted as a result of basinward progradation of the platform facies.

\section{Platform facies}

The platform facies consists of (oolitic) carbonates and minor amounts of dolomite. Locally, e.g. in the Dutch Peel area and the adjacent German area, in Durham County in the UK, in Poland and on Ringkøbing-Fyn High in Denmark, small bryozoan and stromatolite bioherms are encountered on the edge of the shelf (Teichmüller, 1957; Kerkmann, 1969; Clark \& Tallbacka, 1980; Füchtbauer, 1980; Paul, 1980; Taylor, 1998; Peryt \& Raczylski, 1999). The Durham reef is fringed on the shoreward side with dolomitized and porous oolite sheets (Smith, 1981). Reefs have developed close to the platform, and on local intra-basinal highs.

Paul (1980) described an example from the southern Harz (the so-called Römerstein), where an algal reef developed upon the stump of a Lower Rotliegend volcano. Peryt \& Raczylski (1999) described the occurrence of reefs in the central parts of the basin in Poland. These reefs were related to elevations in the Zechstein substrate. They are up to $1 \mathrm{~km}$ wide, with a length varying from a few to over $10 \mathrm{~km}$. Hights were encountered of up to $80 \mathrm{~m}$.

In the western offshore area and NE Belgium, platform carbonates grade southward into sandstones, locally with a high carbonate content (Geluk et al., 1996). Around the NW part of the Texel-IJsselmeer High, some local areas of platform facies have existed (RGD, 1991a,b; Van der Poel, 1987), similar to the Ringkøbing-Fyn and Mid North Sea High (Vejbæk, 1990; Taylor, 1998).

\section{Commercial gas reservoirs}

Commercial gas reservoirs in the $\mathrm{Z1}$ Carbonate Member occur in platform dolomites in a limited number of areas, e.g. in the UK Southern North Sea (Hewett Field: Cooke-Yarborough, 1991; Southwood \& Hill, 1995) and in the Q5 block (well Q5-2). The reservoir in the Hewett field shows an extremely heterogeneous porosity distribution, related to a combination of both depositional-facies variations and diagentic effects (Southwood \& Hill, 1995). Best porosities occur in the upper part of the member. Also the Auk and Argyll oil fields, immediately north of the Mid North Sea High produce from this member (Brennand \& Van Veen, 1975). In Poland, recently a number of discoveries have been made in small-scale reefs in the basin centre (Peryt \& Raczylski, 1999).

Gas shows have been reported from basal Zechstein carbonates in several wells in the Netherlands, but these rocks are generally too tight for commercial production. In some cases, though, limited production has been established from these rocks, i.e. at the Ten Boer-1 well in the northern Netherlands, where gas was discovered in basal Zechstein carbonates several years in advance of the discovery of the underlying Groningen field (Stäuble \& Milius, 1970).

\section{Z2 Carbonate Member (Hauptdolomit/Stinkkalk)}

The transgression of the second classic Zechstein cycle was not as extensively as those of the $\mathrm{Z1}$ and Z3. As a consequence, the southern limit of the Z2 Carbonate does not coincide with that of the $\mathrm{Z} 1$ and Z3 Carbonate, but remains well to the north of it. The facies map of the Z2 Carbonate Member (Fig. 7) has been constructed based upon publications and well data. The map of the eastern Netherlands was adopted from the publication by Van der Sande et al. (1996), and is based upon 3-D seismic data (Fig. 3). Outside this area, the map is based upon well data.

\section{Basin facies}

The basin facies comprises dark coloured, bituminous, finely laminated carbonates, the so-called Stinkkalk (fetid limestone). These rocks have sourcerock potential for oil and gas, with a TOC content of up to $1.2 \%$ (Gerling et al., 1996b; Lokhorst, 1998). They have a very uniform appearance on wireline logs, with high gamma-ray log readings and a thickness of 8-12 $\mathrm{m}$. They occur throughout the Netherlands offshore area, including the northern Central North Sea Graben and the Elbow Spit High. Based upon the geometry of the Z2 Carbonates, water depths of up to $200 \mathrm{~m}$ are assumed in this basin (Taylor, 1998).

In the vicinity of the carbonate platform facies, slumps have been identified within this facies, by means of both 3-D seismic data (Van der Sande et al., 1996) and well data (Amiri-Garoussi \& Taylor, 1992). The slumps consist of displaced shelf deposits, redeposited in deeper water. They originated from both the southern platform and the Mid North Sea High.

\section{Slope facies}

The slope facies consists of light-coloured limestones and dolomites, and redeposited platform sediments 


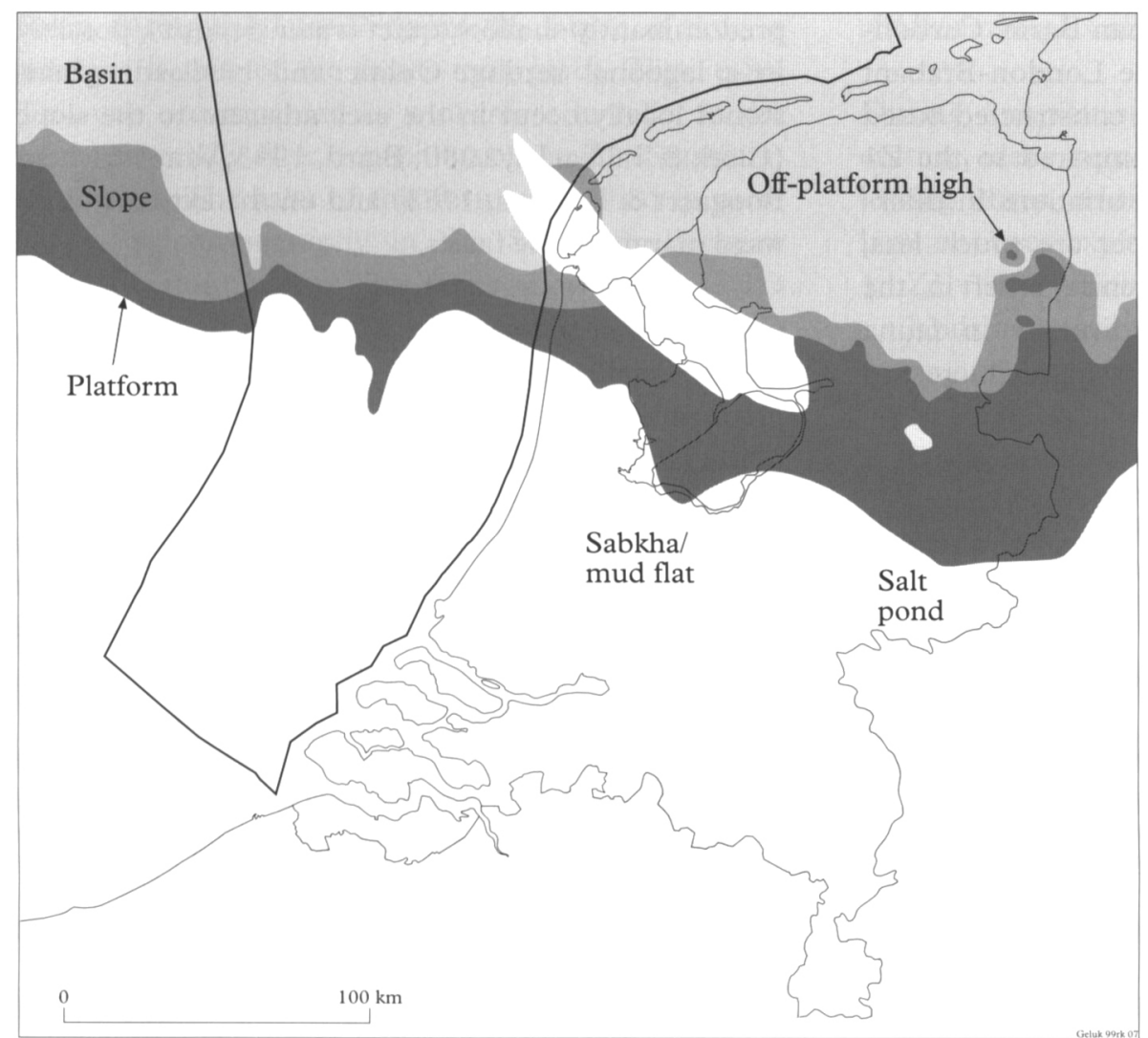

Fig. 7. Facies map of the Z2 Carbonate Member. This map is based on a 3-D map in the eastern Netherlands (Van der Sande et al., 1996) and on well data in the remaining part of the area. The UK part has been adopted from Cameron et al. (1992), the German area from Strohmenger et al. (1996a). The light areas in the onshore part of the Netherlands are highs where the Zechstein has been eroded in Late Jurassic to Early Cretaceous times.

by slumps, grain and mass flows. In the eastern Netherlands, the slope facies reaches a thickness of over $200 \mathrm{~m}$ (Van der Sande et al., 1996). In the western offshore (southern $\mathrm{K}$ and L quads), well data suggest a rapid transition from platform to basin in the southern K blocks; most probably a very steep slope existed there.

\section{Platform facies}

In the area of the platform facies, the Z2 Carbonate comprises a complex of oolitic, pelletoidal, bioclastic and pisolitic grainstones (Clark, 1986; Van der Baan, 1990). 3-D seismic interpretation (Van der Sande, 1996) revealed that the outline of this platform is highly complex, and does not form a single entity. Isolated off-platform highs have been documented by Van der Sande et al. (1996) in the eastern Netherlands, by Gerling et al. (1996a) and Strohmenger et al. (1996a,b,c) in Germany, and by Wagner (1994) in Poland. They appear to be limited to the southern margin of the basin (Strohmenger et al., 1996c). According to Strohmenger et al. (1996c) their distribution was controlled by the interaction of sea-level fluctuations and paleorelief.

Deposition on the platform took place in shallow water, and witnessed occasional subaerial exposure (Van der Baan, 1990). Anhydrite beds are common in this succession (Brueren, 1959; NITG, 1998), interpreted to represent intercalated sabkha deposits. To the south, the platform was bordered by a complex of sabkhas and salt ponds. Locally in these ponds, the Z1 Salt passes upwards into Z2 Salt, with no record of the Z2 transgression (Winterswijk-Zeddam-Isselburg area: NITG, 1998).

\section{Commercial gas reservoirs}

Commercial gas reservoirs are limited mainly to the eastern Netherlands (Van der Sande et al., 1996; Brueren, 1959) and adjacent parts of Germany (Stohmenger et al., 1996a). They form the best producing reservoirs of the Zechstein (Clark, 1986). Reservoir rocks occur in all facies types, but the best producing reservoirs occur in the slope deposits (Clark, 1986). In the eastern Netherlands, production depends largely upon the presence of fractures (Frikken, 1999).

In Germany and Poland, off-platform highs form the main exploration target. Exploration resulted there in a number of oil and gas discoveries, of which the Barnówko-Mosto-Buszewo oil and gas field in Poland is the largest (Górski et al., 1999). In eastern Germany, exploration mainly resulted in the discovery of a number of high-nitrogen fields (Gerling et al., 1996a,b).

\section{Z3 Carbonate Member (Plattendolomit)}

The Z3 Carbonate marks the most important transgression of the Zechstein. It flooded the entire basin 
margin area of the Southern Permian Basin. Carbonates occur up to the fringes of the London-Brabant Massif. The map (Fig. 8) has been constructed based upon well data and literature. Compared to the $\mathrm{Z1}$ and Z2 Carbonate members, the variations in thickness in the $\mathrm{Z} 3$ Carbonate Member are much less, which indicates a much more gentle relief in the basin. The scarcity and lack of diversity in fauna points according to Taylor (1998) to slightly increased salinities in the basin.

\section{Basin facies}

The basinal facies comprises a dark-coloured limestone of a few meters in thickness. These are not always very easy to distinguish from the overlying Main Anhydrite Member. Water depths in the basin were up to several tens of meters.

\section{Slope facies}

The slope facies comprises laminated and bioturbated carbonate mudstones and silty dolomites. Compared to the $\mathrm{Z} 1$ and $\mathrm{Z} 2$ Carbonate Members, the slope was not very well developed during deposition of the Z3 Carbonate.

\section{Platform facies}

The platform facies consists predominantly of grey microcristalline dolomites and algal boundstones. These are considered by Taylor (1998) to represent predominantly shallow, quiet-water deposits, possibly in a lagoonal setting. Oolitic and bioclastic grainstones locally occur in the area adjacent to the slope (Clark \& Tallbacka, 1980; Baird, 1993; Van Adrichem Boogaert \& Burgers, 1983) and on the extreme landward margin of the facies.

\section{Commercial reservoirs}

Commercial reservoirs are limited to the dolomitized platform facies and occur mainly in the western part of the Netherlands. The best reservoirs are formed by oolitic and leached algal deposits (Van Lith, 1983; Van Adrichem Boogaert \& Burgers, 1983). Early diagenetic processes were responsible for most of the porosity in the unit in block P6 (Van der Poel, 1989).

\section{Discussion}

The present contribution focuses on the depositional history of the Zechstein carbonates and the reliability of the maps. At the end of the following discussion, some new ideas regarding additional hydrocarbon targets originating from this assessment will be presented.

\section{Depositional history of the Zechstein carbonates}

The facies maps of the Zechstein carbonate illustrate the progradational infill of the Southern Permian

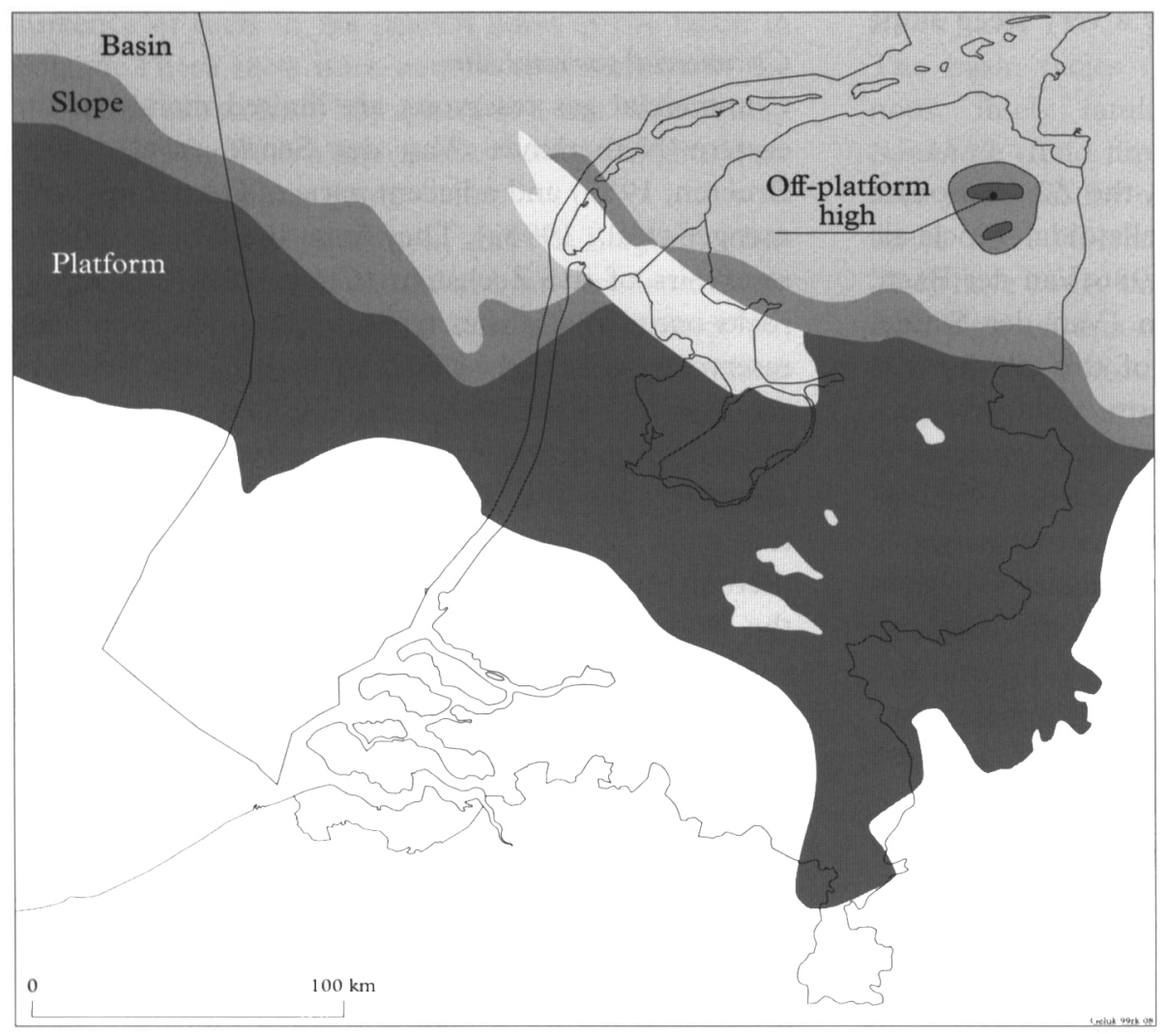

Fig. 8. Facies map of the $\mathrm{Z} 3$ Carbonate Member. This map is based on well data and literature. The UK map has been adopted from Cameron et al. (1992), the German part from Richter-Bernburg (1955). The light areas in the onshore part of the Netherlands are highs where the Zechstein has been eroded in Late Jurassic to Early Cretaceous times. 
Basin during the Late Permian. In course of time, a northward shift of the facies took place (Figs. 6-8). This was accompanied by a decrease in relief in the basin, especially after deposition of the Z2 (Stassfurt) Formation. The salts of this formation filled in most of the paleotopography in the Southern Permian Basin (Taylor, 1998). The maps show that the Z3 transgression was the most important flooding during the Zechstein.

The origin of the relief in the basin is, however, not clear. At the end of the deposition of the Upper Rotliegend, the relief had been levelled out for the most part, and a slightly inclined surface can be assumed (Geluk, 1999). It has been suggested (M.A. Ziegler, 1989; Geluk, 1999) that extension during deposition of the $\mathrm{Zl}$ (Werra) Formation (the Tubantian I pulse) was responsible for the development of the relief in the basin. In this way, the expansion of the Zechstein deposits over previous Upper Rotliegend highs can be explained. Faulting continued during deposition of the $\mathrm{Zl}$ (Werra) Formation, and influenced the paleogeography of the Z2 Carbonate Member.

\section{Reliability of the maps}

The approach of composing one facies map for each carbonate member, as used in the present contribution and elsewhere (Cameron et al., 1992; Wagner, 1994), has some limitations. The most obvious one is that several high-resolution sea-level fluctuations occurred within the carbonate members (Clark, 1986; Tucker, 1991; Strohmenger et al., 1996b). Two cycles have been identified in the $\mathrm{Z} 1$ Carbonate Member, up to seven cycles in the $\mathrm{Z} 2$ Carbonate Member. These fluctuations caused a cyclic shifting of the facies domains during deposition of the carbonates (figures 9-11 in Strohmenger et al., 1996b). By assuming one single facies for the entire carbonate member, these fluctuations are not accounted for.

The database for the map causes some limitations. Literature shows the importance of 3-D seismics in Zechstein hydrocarbon exploration (Maureau \& Van Wijhe, 1979; Karnin et al., 1992; Górski et al. 1999; Peryt \& Raczylski, 1999). Only the eastern part of the Z2 Carbonate facies map is based upon 3-D data; the other maps are based upon well-data.

The facies maps can be regarded as to present an overall impression of the facies; 3-D seismic interpretation needs to be included to refine this picture. Furthermore, it is advised to make facies maps for the individual high-resolution sequences of the carbonates. Such a study requires a close integration of core and well-log data with 3-D seismic interpretation.

\section{Additional exploration potential}

During compilation of the maps and the study of literature, ideas were developed with respect to the following three additional hydrocarbon plays, which have not been explored in the Netherlands.

1. Z1 reefs, which could be located in the Netherlands in areas of Lower Rotliegend volcanic activity (cf. Geluk, 1997), i.e. in the Central Graben/Mid North Sea High areas and the eastern Netherlands. This has recently also been suggested by Frikken (1999) for the eastern Netherlands. The reefs can occur in relation to topographical base-Zechstein highs elsewhere in the Netherlands.

2. Z2 displaced carbonates in the western offshore. In the southern $\mathrm{K}$ and $\mathrm{L}$ quads, a steep slope existed, which was favourable for the initiation of slumps and other mass flows into the basin.

3. Furthermore, $\mathbf{Z 2}$ off-platform highs may occur in this area; they have not been identified during the review of well data.

For successfull exploration of these plays, a detailed 3-D interpretation and high-resolution sequence stratigraphy form a prerequisite.

\section{Conclusions}

The main conclusions of this paper are:

1. the facies belts of the Zechstein carbonates were initially controlled by the paleorelief at the end of the deposition of the Upper Rotliegend and extensional tectonic movements of the Tubantian I phase during deposition of the $\mathrm{Z} 1$ (Werra) Formation;

2. the facies maps in the present contribution have been designed for regional geological correlations, not for prospect identification; detailed 3-D mapping of the high-resolution sequences has been shown by Strohmenger et al. (1996a) to be the successful approach;

3. two unexplored hydrocarbon plays have been identified in the Netherlands: reefs in the Z1 Carbonate Member and off-platform highs and turbidites in the Z2 Carbonate Member.

\section{Acknowledgements}

The author is much indebted to the valuable suggestions made upon a first version of this manuscript by Dr. H.W. Frikken and Dr. J.A.M. Kenter, which led to significant improvements. 


\section{References}

Amiri-Garroussi, K. \& Taylor, J.C.M., 1992. Displaced carbonates in the Zechstein of the UK North Sea. Marine and Petroleum Geology 9: 186-196.

Baird, A., 1993. An assessment of the reservoir potential of the Zechstein of the $P$ and $Q$ quadrants and adjacent onshore areas, the Netherlands. Open-file Report Stratigraphic Services International ltd (Surrey, UK): $44 \mathrm{pp}$.

Brennand, T.P. \& Van Veen, F.R., 1975. The Auk oilfield. In: Woodland, A.W. (ed.): Petroleum and the continental shelf of NorthWest Europe. Applied Science Publishers (London): 275-283.

Brueren, J.W.R., 1959. The stratigraphy of the Upper Permian 'Zechstein' Formation in the Eastern Netherlands. In: I giacimenti gassiferi dell' Europa Occidentale - Atti del Convegno (Milano, 1957) 1:243-274.

Cameron, T.D.J., Crosby, A., Balson, P.S., Jeffery, D.H., Lott, G.K., Bulat, J. \& Harrison, D.J., 1992. The geology of the southern North Sea. United Kingdom Offshore Regional Report, British Geological Survey: $152 \mathrm{pp}$.

Clark, D.N., 1986. The distribution of porosity in Zechstein carbonates. In: Brooks, J., Goff, J. \& Van Hoorn, B. (eds.): Habitat of Paleozoic gas in NW Europe. Geological Society Special Publication 23: 121-149.

Clark, D.N. \& Tallbacka, L., 1980. The Zechstein deposits of southern Denmark. In: Füchtbauer, H. \& Peryt, T. (eds.): The Zechstein basin with emphasis on carbonate sequences. Contributions to Sedimentology 9: 205-231.

Cooke-Yarborough, P., 1991. The Hewett Field, blocks 48/28-2930, 52/4a-5a, UK North Sea. In: Abbots, I.L. (ed.): United Kingdom oil and gas fields, 25 years Commemorative Volume. Geological Society London Memoir 14: 433-442.

Demyttenaere, R., 1989. The post-Paleozoic geological history of north-eastern Belgium. Mededelingen Koninkliike Academie van Wetenschappen, Letteren en Schone Kunsten van België 51: 51-81.

Dorsman, L., 1954. Geological occurrence of natural gas in the Netherlands. Geologie en Mijnbouw 16: 443-448.

Frikken, H.W., 1999. Reservoir-geological aspects of productivity and connectivity of gas reservoirs in the Netherlands. Ph.D. thesis Delft University of Technology: $92 \mathrm{pp}$.

Füchtbauer, H., 1980. Composition and diagenesis of a stromatolitic bryozoan bioherm in the Zechstein 1 (northwestern Germany). In: Füchtbauer, H. \& Peryt, T. (eds.): The Zechstein basin with emphasis on carbonate sequences. Contributions to Sedimentology 9: 233-251.

Galloway, W.E., 1989. Genetic stratigraphic sequences in basin analysis I: architecture and genesis of flooding-surface bounded depositional units. American Association of Petroleum Geologists Bulletin 73: 125-142.

Geluk, M.C., 1997. Palaeogeographic maps of Moscovian and Artinskian; contributions from the Netherlands. In: CrasquinSoleau, S. \& De Wever, P. (eds.): Peri-Thethys stratigraphic correlations. Geodiversitas 19: 229-234.

Geluk, M.C., 1999. Late Permian (Zechstein) rifting in the Netherlands: models and implications for petroleum geology. Petroleum Geoscience 5: 189-199.

Geluk, M.C., Plomp, A. \& Van Doorn, Th.H.M., 1996. Development of the Permo-Triassic succession in the basin fringe area, southern Netherlands. In: Rondeel, H.E., Batjes, D.A.J. \& Nieuwenhuijs, W.H. (eds.): Geology of gas and oil under the Netherlands. Kluwer (Dordrecht): 57-78.

Geluk, M.C., Van Wees, J.D., Grönloh, H. \& Van Adrichem Boogaert, H.A., 1997. Palaeogeography and palaeotectonics of the Zechstein (Upper Permian) in the Netherlands. In: Proceed- ings $13^{\text {th }}$ International Congress on the Carboniferous-Permian (Krakow, 1995). Prace Panstwowego Instytut Geologicznego 157(2): 63-75.

Gerling, P., Piske, J. Rasch, H.-J. \& Wehner, H., 1996a. Paläogeographie, Organofazies und Genese von Kohlwasserstoffern im Stassfurt-Karbonat Ostdeutschlands (1) Sedimentationsverlauf und Muttergesteinsausbildung. Erdöl Erdgas Kohle 112: 13-18.

Gerling, P., Piske, J. Rasch, H.-J. \& Wehner, H., 1996b. Paläogeographie, Organofazies und Genese von Kohlwasserstoffern im Stassfurt-Karbonat Ostdeutschlands (2) Genese von Erdölen und Erdölbegleitgasen. Erdöl Erdgas Kohle 112: 152-157.

Górski, M., Wojtkowiak, Z. \& Radecki, S., 1999. Barnówko-MostoBuszewo (BMB) the largest crude oil deposit in Poland. Petroleum Geoscience 5: 5-15.

Hilden, H.D. (ed.), 1988. Geologie am Niederrhein. Geologisches Landesamt Nordrhein-Westfalen (Krefeld): 142 pp.

Karnin, W.D., Rockenbauch, K. \& Ruijtenberg, P.A., 1992. The effect of the succes of 3D seismic data on the exploration and appraisal of Zechstein targets in NW Germany. First Break 10: 233-240.

Kerkmann, K., 1969. Riffe und Algenbänke im Zechstein von Thüringen. Freiberger Forschungshefte C 252: 85 pp.

Lokhorst, A. (ed.), 1998. The Northwest European gasatlas. Netherlands Institute of Applied Geoscience TNO (Haarlem); ISBN 90-72869-60-5.

Maureau, G.T.F.R. \& Van Wijhe, D.H., 1979. The prediction of porosity in the Permian (Zechstein 2) Carbonate of eastern Netherlands using seismic data. Geophysics 44: 1502-1517.

NITG (Netherlands Institute of Applied Geoscience TNO), 1998. Geological atlas of the subsurface of the Netherlands, explanation to map sheet X Almelo-Winterswijk. NITG (Haarlem): $134 \mathrm{pp}$.

Paul, J., 1980. Upper Permian algal stromatolite reefs, Harz Mountains (F.R. Germany). In: Füchtbauer, H. \& Peryt, T. (eds.): The Zechstein basin with emphasis on carbonate sequences. Contributions to Sedimentology 9:253-268.

Peryt, T. \& Raczylski, P., 1999. Upper Permian bioherms in the basin centre: Zechstein limestone in western Poland. Abstracts $14^{\text {th }}$ International Congress on the Carboniferous-Permian, (Calgary, 1999): 112.

RGD (Rijks Geologische Dienst), 1991a. Geological atlas of the subsurface of the Netherlands, explanation to map sheet I Vlieland-Terschelling. RGD (Haarlem): $77 \mathrm{pp}$.

RGD (Rijks Geologische Dienst), 1991b Geological atlas of the subsurface of the Netherlands, explanation to map sheet II Ameland-Leeuwarden. RGD (Haarlem): $87 \mathrm{pp}$.

RGD (Rijks Geologische Dienst), 1993a. Geological atlas of the subsurface of the Netherlands: sheet IV Texel-Purmerend. RGD (Haarlem): 127 pp.

RGD (Rijks Geologische Dienst), 1993b. Geological atlas of the subsurface of the Netherlands: sheet V Sneek-Zwolle. RGD (Haarlem): $126 \mathrm{pp}$.

RGD (Rijks Geologische Dienst), 1995. Geological atlas of the subsurface of the Netherlands: sheet III Rotummeroog-Groningen. RGD (Haarlem): 113 pp.

Richter-Bernburg, G., 1955. Statigraphische Gliederung des deutschen Zechsteins. Zeitschrift der deutschen geologischen Gesellschaft 105: 593-645.

Sannemann, D., Zimdars, J. \& Plein, E., 1978. Der basale Zechstein (A2-T1) zwischen Weser und Ems. Zeitschrift der deutschen geologischen Gesellschaft 129: 33-69.

Smith, D.B., 1981. The Magnesian Limestone (Upper Permian) reef complex of northeastern England. In: Toomey, D.F. \& Wilson, J.L. (eds.): European fossil reef models. Society of Economic Paleontologists and Mineralogists Special Publication 30: 161-186. 
Southwood, D.A. \& Hill, W.O.R., 1995. The origin and distribution of porosity in the Zechsteinkalk (Upper Permian) of Hewett Field, Southern North Sea. Petroleum Geoscience 1: 289-302.

Stäuble, A.J. \& Milius, G., 1970. Geology of the Groningen gasfield, Netherlands. In: Halbouty, M.T. (ed.): Geology of giant petroleum fields. American Association of Petroleum Geologists Memoir 14: 359-369.

Strohmenger, C. \& Strauss, C., 1996. Sedimentology and palynofacies of the Zechstein 2 Carbonate (Upper Permian, Northwest Germany): implications for sequence stratigraphic subdivision. Sedimentary Geology 102: 55-77.

Strohmenger, C., Antonini, M., Jäger, G., Rockenbauch, K. \& Strauss, C., 1996a. Zechstein 2 Carbonate reservoir facies distribution in relation to Zechstein sequence stratigraphy (Upper Permian, Germany): an integrated approach. Bulletin du Centre de Recherche et Exploration-Production Elf Aquitain 20(1): 1-35.

Strohmenger, C., Voigt, E. \& Zimdars, J., 1996b. Sequence stratigraphy and cyclic development of Basal Zechstein carbonateevaporite deposits with emphasis on Zechstein 2 off-platform carbonates (Upper Permian, Northeast Germany). Sedimentary Geology 102: 33-54.

Strohmenger, C., Voigt, E. \& Zimdars, J., 1996c. Einfluss von Eustasie und Paläorelief auf die sedimentologische und diagenetische Entwicklung der Zechstein 2 Karbonate (Ober-Perm, Nordost-Deutschland). Erdöl Erdgas Kohle 109: 445-450.

Taylor, J.C.M., 1998. Upper Permian - Zechstein. In: Glennie, K.W. (ed.): Petroleum geology of the North Sea (4th ed.). Blackwell Science: 174-212.

Teichmüller, R., 1957. Ein Querschnitt durch den Südteil des Niederrheinischen Zechsteinbeckens. Geologisches Jahrbuch 73: 39-50.

Tucker, M.E., 1991. Sequence stratigraphy of carbonate - evaporite basins: models and applications to the Upper Permian (Zechstein) of northeast England and adjoining North Sea. Journal of the Geological Society 148: 1019-1036.

Van Adrichem Boogaert, H.A. \& Burgers, W.F.J., 1983. The development of the Zechstein in the Netherlands. Geologie en Mijnbouw 62: 83-92.

Van Adrichem Boogaert, H.A. \& Kouwe, W., 1993-1997. Stratigraphic nomenclature of the Netherlands; revision and update by the RGD and NOGEPA. Mededelingen Rijks Geologische Dienst 50.
Van der Baan, D., 1990. Zechstein reservoirs in the Netherlands. In: Brooks, J. (ed.): Classic petroleum provinces. Geological Society Special Publication 50: 379-398.

Van der Poel, A.B., 1987. Porosity development of some uplifted carbonates of the southern Permian Basin (Texel-IJsselmeer High, the Netherlands and The Harz, Germany). Mededelingen Rijks Geologische Dienst 41: 1-17.

Van der Poel, A.B., 1989. A case study on the hydrocarbon geology of Upper Permian (Zechstein 3) carbonates in licence P6, the Netherlands' offshore. Geologie en Mijnbouw 68: 285-296.

Van der Sande, J.M.M., Reijers, T.J.A. \& Casson, N., 1996. Multidisciplinary exploration strategy in the Northeast Netherlands Zechstein 2 Carbonate play, guided by 3D seismic. In: Rondeel, H.R., Batjes, D.A.J. \& Nieuwenhuijs, W.A. (eds.): Geology of gas and oil under the Netherlands. Kluwer Academic Publishers (Dordrecht): 125-142.

Van Lith, J.G.J., 1983. Gas fields of the Bergen concession, the Netherlands. Geologie en Mijnbouw 62: 63-74.

Van Waterschoot van der Gracht, W.A.J.M., 1918. Eindverslag over de onderzoekingen en uitkomsten van de Dienst der Rijks-opsporing van Delfstoffen in Nederland. Amsterdam: $664 \mathrm{pp}$.

Vejbæk, O.V., 1990. The Horn Graben and its relationship to the Oslo Graben and the Danish Basin. Tectonophysics 178: 29-49.

Visser, W.A., 1955. The Upper Permian in the Netherlands. Leidsche Geologische Mededelingen 20: 186-194.

Wagner, R., 1994. Stratygrafia osadów i roswój basenu Cechsztynskiego na nizu Polskim (with full English translation: Stratigraphy and evolution of the Zechstein basin in the Polish Lowlands). Prace Panstwowego Instytutu Geologicznego 146: $71 \mathrm{pp.}$

Wolburg, J., 1957. Ein Querschnitt durch den Nordteil des Niederrheinischen Zechsteinbeckens. Geologisches Jahrbuch 73: 7-38.

Wolf, R., 1985. Tiefentektonik des linksniederrheinischen Steinkohlengebietes. Beiträge zur Tiefentektonik westdeutsche Steinkohlenlagerstätten. Geologisches Landesamt Nordrhein-Westfalen (Krefeld): 105-167.

Ziegler, M.A., 1989. North German Zechstein facies patterns in relation to their substrate. Geologische Rundschau 78:105-127.

Zuurdeeg, B.W., Coenegracht, Y.M.A., Mebius, J.E. \& Van der Weiden, M.J.J., 1984. Prognose van het mineraalwater van Winterswijk. Internal Report Vening Meinesz Laboratorium, Rijksuniversiteit Utrecht: $22 \mathrm{pp}$. 